\title{
Correction to: An upper bound for the number of gravitationally lensed images in a multiplane point-mass ensemble
}

\author{
Sean Perry ${ }^{1}$ (iD
}

Published online: 19 May 2021

(c) Springer Nature Switzerland AG 2021

\section{Correction to: Analysis and Mathematical Physics (2021) 11:52 https://doi.org/10.1007/s13324-021-00478-4}

The article An upper bound for the number of gravitationally lensed images in a multiplane point-mass ensemble, written by Sean Perry, was originally published online on 9th February 2021 with Open Access under a "This article is licensed under a Creative Commons Attribution 4.0 International License, which permits use, sharing, adaptation, distribution and reproduction in any medium or format, as long as you give appropriate credit to the original author(s) and the source, provide a link to the Creative Commons licence, and indicate if changes were made. The images or other third party material in this article are included in the article's Creative Commons licence, unless indicated otherwise in a credit line to the material. If material is not included in the article's Creative Commons licence and your intended use is not permitted by statutory regulation or exceeds the permitted use, you will need to obtain permission directly from the copyright holder. To view a copy of this licence, visit http://creativecommons.org/licenses/by/4.0/". After publication in volume 11 issue 2, page 1-13, the author(s) decided to cancel the Open Access. Therefore, the copyright of the article has been changed on 2nd May to (C) Springer Nature Switzerland AG 2021 with all rights reserved.

Publisher's Note Springer Nature remains neutral with regard to jurisdictional claims in published maps and institutional affiliations.

The original article can be found online at https://doi.org/10.1007/s13324-021-00478-4.

Sean Perry

sperry9@fau.edu

1 Florida Atlantic University, Boca Raton, USA 